\title{
3-Hidroksipiridin-4-oni (II. dio): Biološka primjena kao kelatora željeza
}

DOI: $10.15255 / K U I .2015 .051$

KUI-3/2017

Pregledni rad

Prispjelo 15. prosinca 2015.

Prihvaćeno 1. veljače 2016.

\section{Ž. Car, ${ }^{*}$ V. Petrović Perokovići S. Tomić Pisarović}

Zavod za organsku kemiju, Kemijski odsjek, Prirodoslovno-matematički fakultet, Sveučilište u Zagrebu, Horvatovac 102A, 10000 Zagreb

\author{
|| Sažetak \\ Selektivnost prema keliranju trovalentnih kationa metala, u prvom redu Fe(III), osnova je brojnih bioloških uči- \\ naka derivata 3-hidroksipiridin-4-ona. Ti spojevi najviše potencijala pokazuju u liječenju oboljenja uslijed kojih \\ dolazi do nakupljanja željeza u organizmu, kao što su razna krvna oboljenja poput talasemije i hemokromatoze \\ te u liječenju neurodegenerativnih bolesti, primjerice Alzheimerove bolesti. Osim deferiprona, koji je već više \\ od 30 godina u kliničkoj upotrebi kao kelator Fe(III), u ovom radu dan je pregled i ostalih najznačajnijih kelatora \\ 3-hidroksipiridin-4-onske strukture s potencijalnom biološkom primjenom. \\ \| Ključne riječi \\ 3-hidroksipiridin-4-oni, željezo(III), kelatoterapeutici, deferipron, talasemija, Alzheimerova bolest
}

\section{Uvod}

3-Hidroksipiridin-4-oni (3,4-HP, slika 1) zanimljiva su skupina polifunkcionalnih, heterocikličkih spojeva. Selektivni su ligandi trovalentnih tvrdih metalnih iona, primjerice $\mathrm{Fe}(\mathrm{III})$ i Al(III), u području fiziološkog pH, što je osnova njihova raznolikog biološkog djelovanja. Istražuju se ponajprije kao agensi za uklanjanje navedenih metalnih iona, ali i kao antibakterijski i antitumorski agensi te kao potencijalni antimalarici i antidementici. ${ }^{1-3}$<smiles>[R]c1c(O)c(=O)ccn1[R]</smiles>

$$
\begin{aligned}
& \mathrm{R}^{1}=\text { alkil } \\
& \mathrm{R}^{2}=\text { alkil, aril } \\
& \mathrm{R}^{1}=\text { alkyl } \\
& \mathrm{R}^{2}=\text { alkyl, aryl } \\
& \mathrm{R}^{1}=\mathrm{R}^{2}=\mathrm{CH}_{3} \\
& \text { deferipron/deferiprone }
\end{aligned}
$$

Slika 1 - Strukturna formula 3,4-HP derivata i deferiprona

Fig. 1 - Structural formula of 3,4-HP derivatives and deferiprone

3-Hidroksi-1,2-dimetilpiridin-4-on (deferipron, Ferriprox ${ }^{\circledR}$, slika 1) jedini je predstavnik ove skupine spojeva u kliničkoj uporabi. Trenutačno se najviše upotrebljava za liječenje nasljednih krvnih oboljenja, kao što su primarna hemokromatoza ili različite vrste talasemija. Primarna hemokromatoza je poremećaj u metabolizmu željeza čija

*Autor za dopisivanje: Dr. sc. Željka Car e-pošta: zcar@chem.pmf.hr je posljedica njegovo pojačano nakupljanje u organizmu. Glavni oblik liječenja težih oblika talasemija česte su transfuzije krvi koje također dugoročno vode do povećane koncentracije tog metala. Kelatori koji imaju sposobnost selektivnog vezanja željeza, poput deferiprona, upotrebljavaju se u liječenju tih bolesti. Do otkrića deferiprona, kao jedini klinički lijek u tu svrhu upotrebljavao se desferioksamin B (DFO, Desferal $\left.{ }^{\circledR}\right)^{1}$

Glavni nedostatak DFO-a jest da je inaktivan kada se primjenjuje oralno te se mora primjenjivati intravenozno, što pacijenti zajedno s brojnim i dugotrajnim transfuzijama krvi dosta teško podnose.

3,4-HP derivati prema svojim su fizikalno-kemijskim i farmakološkim parametrima vrlo dobri kandidati za keliranje željeza in vivo ali i oralnu primjenu, te se u tu svrhu najviše istražuju. Osim njihove uporabe u liječenju oboljenja kod kojih dolazi do nakupljanja željeza, detaljnije će biti opisana i istraživanja provedena u svrhu ispitivanja njihove antineurodegenerativne aktivnosti s kraćim osvrtom na antibakterijsku, antiadhezijsku i antitumorsku aktivnost. Ispitivanje biološkog učinka tih derivata te ponajprije njihova sinteza unazad nekoliko godina dio su i naših istraživanja. ${ }^{4-7}$

\section{Uporaba 3,4-HP derivata u liječenju talasemija i srodnih krvnih oboljenja}

Željezo je biometal iznimne važnosti za ljudski organizam jer je uključen u mnoge važne biološke procese. Potreban je za brojne vitalne funkcije uključujući rast, reprodukciju i imunitet. Ukupna razina željeza u organizmu zdravog 
čovjeka konstantna je i iznosi otprilike $35-45 \mathrm{mg} \mathrm{kg}^{-1} .^{8}$ Preporučene dnevne doze za unos tog metala su $15 \mathrm{mg}$ na dan i mogu varirati ovisno o dobi i spolu. Oko 70 \% željeza $\mathrm{u}$ organizmu nalazi se u metaloproteinima poput hemoglobina u krvi, mioglobina u mišićima koji su specijalizirani za transport i čuvanje kisika ili citokromima koji sudjeluju u sintezi adenozin-trifosfata ( $k$ rat. ATP, engl. adenosine triphosphate). Ostatak željeza nalazi se u jetri, slezeni i koštanoj srži, gdje se skladišti ili je kofaktor različitih enzima. Jedan od važnijih je svakako i enzim ribonukleotid-reduktaza (krat. RR, engl. ribonucleotide reductase). Taj enzim posreduje pri pretvorbi sva četiri ribonukleotida u njihove deoksiribonukleotidne analoge, prekursore potrebne za sintezu DNA. RR je građen od dvije podjedinice R1 i R2. Podjedinica R1 odgovorna je za vezanje ribonukleotida i alosteričkih faktora. Fe(III) igra važnu ulogu u katalitičkoj aktivnosti RR-a jer stabilizira radikal tirozinskog ostatka unutar podjedinice R2. U literaturi su opisane tri glavne klase tog enzima ovisno o metalnom kofaktoru koji trebaju za svoju katalitičku aktivnost. ${ }^{9}$ Klasa I nalazi se u gotovo svim eukariotskim organizmima, u nekim prokariotima i virusima. Dijeli se dodatno u tri podklase (a, b i c) ovisno o slijedu polipeptidnih lanaca te ukupnoj alosteričkoj regulaciji. Ljudski RR pripada klasi la.

Željezo se u organizam unosi u anorganskom obliku ili vezano za hem. Anorgansko željezo mora biti u dvovalentnom Fe(II) obliku kako bi se transportiralo kroz membrane s pomoću odgovarajućih transportnih proteina kao što je transportni protein 1 za dvovalentne metale (krat. DMT1, engl. divalent metal transporter 1). Na svom metaboličkom putu, koji do danas nije još sasvim razjašnjen, željezo alternira između svoja dva oksidacijska stanja, a smatra se da glavnu ulogu u njihovoj izmjeni igraju brojne oksidoreduktaze. Na putu do tkiva, u serumu, željezo se nalazi u svom topljivom obliku vezano na transportni protein transferin (krat. Tf, engl. transferrin) koji se sastoji od dva režnja, C i N. Svaki od njih ima vezno mjesto za Fe(III), koje čine četiri aminokiselinska ostatka (aspartat, histidin i dva tirozinska ostatka) i karbonatni anion. Prilikom vezanja željeza oba režnja podliježu konformacijskim promjenama te Tf veže po dva iona Fe(III) s visokim afinitetom $(\mathrm{pFe}=20,3)^{1}$. Unos željeza u stanicu započinje vezanjem po dvije molekule tako nastalih kompleksa Tf i Fe(III) u homodimerni transferinski receptor 1 (krat. TfR1, engl. transferrin receptor 1) na površini stanice. Nastali kompleks Tf-TfR1 zatim s pomoću endocitoze i membranskih receptora uz stvaranje endosoma ulazi u unutarstanični dio. U endosomu se zbog blago kiselih uvjeta ( $\mathrm{pH}$ 5) otpušta karbonatni ion, što uzrokuje disocijaciju Fe(III) iz veznog mjesta s obzirom da ono postane slabije vezano. Fe(III) se zatim reducira s pomoću oksidoreduktaza u Fe(II) i prenosi na DMT1, koji nadalje transportira željezo preko endosomske membrane u citosol. Iz citosola se transportira u tzv. nestabilni skladišni odjeljak (krat. LIP, engl. labile iron pool) gdje kompleksira sa spojevima male molekulske mase. lako nije još do kraja razjašnjen sastav odjeljka LIP, pretpostavlja se da se željezo u njemu veže uglavnom na citrate, šećere, nukleotide i aminokiseline. Željezo se iz dijela LIP ugrađuje u protein feritin, koji ima svrhu njegova skladištenja unutar stanice.

Agensi koji bi poslužili kao potencijalni kelatori željeza trebali bi moći kompetirati kompleksiranju željeza za transferin, vezati tzv. netransferinsko željezo (engl. non-trans- fferin-bound iron) ili ga vezati unutar odjeljka LIP i feritina. Pretpostavlja se da bi anionski kelatori mogli kompetirati karbonatnom anionu u veznom mjestu i na taj način vezati $\mathrm{Fe}(\mathrm{III})$ iz transferina. Pokazalo se da postoji kooperativna veza između režnjeva $\mathrm{C}$ i $\mathrm{N}$ transferina u fiziološkim uvjetima..$^{10}$ Uslijed konformacijske promjene režnja C, nakon uklanjanja kationa, dolazi do blokade veznog mjesta za karbonatni anion u režnju $\mathrm{N}$. To znači da bi negativno nabijeni kelatori mogli u režnju $\mathrm{N}$ zamijeniti ulogu aniona i vezati Fe(III).

Studije odnosa strukture i aktivnosti (krat. SAR, engl. structure-activity relationship) na nekoliko negativno nabijenih i neutralnih kelatora pokazale su da negativno nabijeni ligandi s vrijednostima pFe većim od 20 uklanjaju Fe(III) preferencijalno s režnja N Tf, dok neutralni ligandi poput 3,4-HP derivata i deferiprona uklanjaju željezo uglavnom s režnja C. Pozitivno nabijeni DFO primjerice, iako posjeduje iznimno visok afinitet za Fe(III) (pFe $=26,6)$, uopće ne veže željezo sa Tf. ${ }^{10}$

U zdravom organizmu održava se ravnoteža između unosa željeza, njegova iskorištenja u staničnim procesima i skladištenju. Homeostaza željeza je strogo reguliran proces, koji se narušava pojavom neke bolesti što može rezultirati povećanim koncentracijama željeza u tkivima. S obzirom na to da željezo redovito alternira između svoja dva redoks-stanja, odnosno prima ili donira elektrone, može pridonijeti stvaranju slobodnih radikala, što je iznimno opasno ako je njegova razina u organizmu iznad dopuštene. $U$ tom smislu željezo tada postaje toksično, a stanice podliježu tzv. oksidativnom stresu. Nastajanje radikalskih vrsta (jedn. 1 - 3), konkretno onih koje uključuju kisik (krat. ROS, engl. reactive oxygen species) uz pomoć željeza opisuje Fentonova reakcija (jedn. 2). ${ }^{11}$ Hidroksilni radikali, koji nastaju tom reakcijom, iznimno su reaktivne vrste i mogu inicirati niz nepoželjnih reakcija te posljedično uzrokovati oštećenje važnih biomolekula (DNA, membranskih lipida, proteina). Takva oštećenja nerijetko uzrokuju mnoga karcinogena oboljenja. Visoke razine tog metala u tkivima mogu rezultirati i smrtnim ishodom.

$$
\begin{gathered}
\mathrm{Fe}^{3+}+\mathrm{O}_{2}^{\cdot-} \rightarrow \mathrm{Fe}^{2+}+\mathrm{O}_{2} \\
\mathrm{Fe}^{2+}+\mathrm{H}_{2} \mathrm{O}_{2} \rightarrow \mathrm{Fe}^{3+}+\mathrm{OH}^{\cdot}+\mathrm{OH}^{-} \\
\text {ukupno: } \mathrm{O}_{2}^{\cdot-}+\mathrm{H}_{2} \mathrm{O}_{2} \rightarrow \mathrm{O}_{2}+\mathrm{OH}^{\cdot}+\mathrm{OH}^{-}
\end{gathered}
$$

Glavni uzrok smrtnosti pacijenata koji boluju od $\beta$-talasemije je srčani zastoj koji se javlja kao posljedica akumuliranja željeza u krvožilnom sustavu. Već spomenuta skupina nasljednih oboljenja talasemije poremećaji su u normalnoj proizvodnji hemoglobina što ima za posljedicu niske razine hemoglobina u krvi i visoku stopu razaranja crvenih krvnih stanica. Hemoglobin je tetramerni protein sastavljen od hema te dva $\alpha$ - $i$ dva $\beta$-polipeptidna lanca. $\beta$-talasemija se javlja kao posljedica poremećaja u sintezi $\beta$-lanca uzrokovanog mutacijom gena. Zbog smanjenog broja $\beta$-lanaca $\alpha$-lanci stvaraju nestabilne proteinske agregate i vode razaranju crvenih krvnih stanica, što u konačnici ima za posljedicu težak oblik anemije. Anemija se u oboljelih liječi dugotrajnim transfuzijama krvi i pojačanim dijetarnim unosom željeza. S obzirom na to da je količina željeza samo u jednoj jedinici krvi oko 200 mg, ono se počinje na- 
kupljati u tkivima i organima i bez odgovarajućeg kelatora pacijenti oboljeli od $\beta$-talasemije, ali i sličnih krvnih oboljenja, poput hemokromatoze, umiru već u vrlo ranoj dobi života. Jedan od limitirajućih faktora, pogotovo za oralno primjenjive kelatore i općenito terapeutike, je njihova molekulska masa. Ona mora biti manja od 500 Da kako bi se kelator mogao uspješno apsorbirati u gastrointestinalnom traktu i prolaziti kroz biomembrane do ciljnog mjesta svog djelovanja u stanicama. Ostali faktori (tzv. Lipinski pravila) već su spomenuta lipofilnost $(\log P<5)$ i ukupni naboj molekule te broj donorskih i akceptorskih skupina za stvaranje vodikovih veza. ${ }^{1,3}$

U liječenju ove bolesti već se dugo vremena kao kelator upotrebljava DFO koji in vivo veže selektivno Fe(III) i stvara komplekse 1 : 1. lako je iznimno učinkovit jer produljuje životni vijek pacijenata, ovaj lijek ima i nekoliko nedostataka. Glavni je nemogućnost njegove oralne administracije, već se primjenjuje intravenozno (16 h dnevno, $5-7$ dana u tjednu), što pacijenti uz transfuzije krvi dosta teško podnose i često odbijaju liječenje. Razlog intravenozne primjene je njegov hidrofilni karakter $(\log P=-2)^{1}$ i velika molekulska masa $(656,79$ Da) zbog koje se lijek ne može apsorbirati kroz membrane gastrointestinalnog trakta.

Deferipron se u liječenju ove bolesti upotrebljava već tridesetak godina (od njegova otkrića 1982. g.) i primjenjuje se oralno. Djeluje tako da veže željezo iz skladišnog proteina feritina, što DFO zbog svoje voluminoznije strukture ne može. No nažalost i ovaj derivat ima svojih nedostataka. Jedan od glavnih je njegov metabolički put (faze I i II, shema 1) u jetri. Naime, hidroksilna skupina piridinonskog skeleta koja je potrebna za kompleksiranje s metalom podložna je glukouronidaciji. Općenito, organizam se koristi postupkom glukouronidacije (enzimski katalizirana $\mathrm{N}$ - ili O-glikozidacija neke tvari glukuronskom kiselinom) kako bi određene tvari učinio topljivijima, te ih time lakše eliminirao iz organizma putem urinarnog trakta ili žuči. Analizom sadržaja urina kod ljudi liječenih ovim terapeutikom te kod štakora u biološkim ispitivanjima, ustanovljeno je da se otprilike $85 \%$ odnosno $44 \%$ doze samoga lijeka nalazi u urinu u obliku 3-O-glukouronidnog konjugata $\mathbf{A}$ koji nema sposobnost kompleksiranja željeza. ${ }^{11-13}$ Stoga se taj lijek mora primjenjivati u visokim dozama kako bi se postigla njegova klinička učinkovitost.

Pored navedenog nedostatka lijek ima i brojne gastrointestinalne nuspojave, a kod nekih je pacijenata (njih oko $2 \%$ zabilježena agranulocitoza (smanjen broj bijelih krvnih stanica), konkretno neutropenija (smanjen broj neutrofilnih granulocita). Navedeni nedostatci glavni su razlog zašto je deferipron u Sjedinjenim Američkim Državama odobren za uporabu tek 2011. godine. DFO i deferipron počinju se 1998. upotrebljavati u kombiniranoj kelatoterapiji. U sekvencijalnoj kombiniranoj terapiji pacijentima se preko dana administrira DFO, a preko noći deferipron, čime je režim liječenja postao mnogo podnošljiviji. Takvim načinom liječenja zabilježene su smanjene razine željeza u jetri, serumu, skladišnom proteinu feritinu, a poboljšana je funkcija krvožilnog sustava.

Derivati 3,4-HP koji su se u potrazi za novim potencijalnim kelatorima željeza pokazali obećavajućima, prema svojim fizikalno-kemijskim svojstvima i preliminarnim istraživanji-<smiles>CCc1c(O)c(=O)ccn1C</smiles>

Shema 1 - Faze I i II metabolizma deferiprona u jetri čovjeka. Od svih prikazanih mogućih metabolita najviše nastaje glukouronida $\mathbf{A}$.

Scheme 1 - Phase I and II of the metabolic pathway of deferiprone in the human liver. The main metabolite formed is glucouronide $\mathbf{A}$. 
Tablica 1 - Novi potencijalni kelatori željeza i njihove vrijednosti pFe i $\log P{ }^{1}$

Table 1 - Novel potential iron chelating agents and their pFe and $\log P$ values. ${ }^{1}$<smiles>[R]c1c(O)c(=O)ccn1[R]</smiles>

\begin{tabular}{|c|c|c|c|c|}
\hline $\begin{array}{c}\text { Spoj } \\
\text { Compound }\end{array}$ & $\mathrm{R}^{1}$ & $\mathrm{R}^{2}$ & $\mathrm{pFe}$ & $\log P$ \\
\hline deferipron & $-\mathrm{CH}_{3}$ & $-\mathrm{CH}_{3}$ & 20,7 & $-0,85$ \\
\hline CP94 & $-\mathrm{CH}_{2} \mathrm{CH}_{3}$ & $-\mathrm{CH}_{2} \mathrm{CH}_{3}$ & 19,7 & 0,85 \\
\hline Car-HP & $\begin{array}{l}-\mathrm{CH}_{2} \mathrm{CH}_{2} \mathrm{COOH} \\
\mathrm{O}\end{array}$ & $-\mathrm{CH}_{3}$ & 21,3 & $-1,89$ \\
\hline Orn-HP & $\mathrm{NH}_{2}$ & $-\mathrm{CH}_{3}$ & 21,9 & $<-2$ \\
\hline Apb-HP & $-\left(\mathrm{CH}_{2}\right)_{3} \mathrm{NHCH}_{2} \mathrm{C}_{6} \mathrm{H}_{5}$ & $-\mathrm{CH}_{3}$ & 21,0 & 0,59 \\
\hline Pip-HP & & $-\mathrm{CH}_{3}$ & 17,4 & 1,06 \\
\hline
\end{tabular}

ma in vitro i in vivo, prikazani su, uz deferipron za usporedbu, u tablici 1 .

Prema navedenim fizikalno-kemijskim parametrima može se zaključiti da bi Car-HP, Orn-HP i Apb-HP uspješno mogli konkurirati transferinu u kompleksiranju željeza. Međutim, $\log P$ vrijednosti Car-HP i Orn-HP ukazuju na moguće probleme vezane za prolaz ovih kelatora kroz stanične membrane, što ne vrijedi za lipofilnije derivate Apb-HP i Pip-HP. Pokusi in vivo biodistribucije kelatora (Car-HP, Orn-HP, Apb-HP, Pip-HP) na štakoru provedeni su tako da su najprije pripravljeni njihovi kompleksi s radioizotopom ${ }^{67} \mathrm{Ga}(\mathrm{III})$. Ga(III) se u organizmu ponaša kao analog Fe(III) i može se vezati na bilo koji protein koji inače veže željezo, kao što je transferin. Spojevi koji uspješno keliraju $\mathrm{Fe}(\mathrm{III}) \mathrm{u}$ pravilu sa sličnim afinitetom vežu i Ga(III). ${ }^{8,14-16}$ Kompleks se pripravlja miješanjem kelatora i kupovnog radioaktivno obilježenog kompleksa galijeva citrata. Potom se administrira u životinju te se one nakon određenog vremenskog razdoblja žrtvuju. Pomoću radiodijagnostičkih metoda izrađuje se profil biodistribucije kompleksa u tkivima i organima na osnovi čega se procjenjuje kakva bi bila distribucija sličnih kompleksa s Fe(III). Rezultati biodistribucije galijevih kompleksa tih spojeva pokazali su da se svi uspješnije izlučuju iz organizma u odnosu na kompleks galijeva citrata koji je upotrijebljen kao standard. Dodatno se pokazalo da Car-HP kompleks dominira u koštanom tkivu, dok se Pip-HP i Apb-HP kompleksi apsorbiraju više u mozgu, što sugerira mogućnost upotrebe u kombiniranim terapijama u liječenju neurodegenerativnih bolesti. $U$ konačnici, može se zaključiti da je različita biodistribucija tih spojeva usko povezana s promjenom supstituenta na dušikovu atomu piridinonskog prstena.

Glavni nedostatak 3,4-HP je i dalje glukouronidacija hidroksilne skupine na položaju 3. U literaturi je opisano nekoliko načina kojima se pokušalo zaobići taj problem. Jedan od glavnih je modifikacija položaja 2 s pomoću supstituenta koji bi bio sterički zahtjevniji od metilne skupine, a da se pritom vrijednost log $P$ drastično ne izmijeni ili supstituenta koji bi stvarao unutarmolekulske vodikove veze s hidroksilnom skupinom i time umanjio njezin nukleofilni karakter u glukouronidaciji. Derivat CP94, s etilnim skupinama na položajima 1 i 2, pokazao se uspješnim u keliranju željeza u modelima in vivo i predložen je za klinička ispitivanja koja su, za sada, u fazi zastoja jer i kod njega ipak dolazi do stvaranja analognog 3-O-glukouronidnog metabolita. ${ }^{11}$ Posljedica druge strategije je priprava nekoliko derivata s amidnim skupinama na položaju 2, koji su rezultirali stvaranjem željenih vodikovih veza te povišenim vrijednostima pFe u odnosu na deferipron. ${ }^{1}$ Ti su derivati još uvijek u fazi dodatnih pokusa in vivo.

Vezanjem više istovrsnih kelirajućih jedinica na zajednički strukturni motiv moguće je pripraviti polidentatne ligande koji bi mogli oponašati kelirajuća svojstva prirodnih siderofora poput DFO-a. Taj je aspekt istraživanja unazad nekoliko godina urodio s dvije skupine heksadentatnih 3,4-HP liganada (slika 2). Kod jednih je zajednički strukturni motiv cis, cis-1,3,5-trimetilcikloheksan-1,3,5-trikarboksilna kiselina (Kempova trikiselina) ${ }^{17}$ na koju su poveznicama različitih duljina vezana tri liganda 3,4-HP, pri čemu su dobiveni derivati $\operatorname{Kemp}(\mathrm{PrHP})_{3}$ i $\operatorname{Kemp}(\mathrm{BuHP})_{3} .{ }^{18}$ Vezanjem derivata 
3,4-HP N-alkilnim poveznicama različitih duljina na nitrilotripropionsku (krat. NTP, engl. nitrilotripropionic acid) ili nitrilotrioctenu kiselinu (krat. NTA, engl. nitrilotriacetic acid), kao zajedničke strukturne motive, pripravljeni su heksadentatni derivati NTP $(\mathrm{PrHP})_{3}$ i NTA $(\text { BuHP })_{3} .{ }^{19}$ Svi navedeni derivati su se iskazali iznimnim afinitetima za Fe(III) s većim vrijednostima pFe od DFO-a i deferiprona.

$\mathrm{NTP}(\mathrm{PrHP})_{3}$ jedini je za sada ispitan in vivo. Kompleksu tog spoja $\mathrm{S}^{67} \mathrm{Ga}$ određen je biodistribucijski profil na štakoru (slika 3). Mjerenja su izvršena radiodijagnostičkim tehnikama u različitim razdobljima od injektiranja (30 min, 60 min i 24 h). Pokazalo se da se kompleks uglavnom izlučuje kroz bubrege i znatno manje apsorbira i zadržava u ostalim tkivima i organima te da se nakon $24 \mathrm{~h}$ od injektiranja ne može više detektirati. Zbog svoje brze i učinkovite eliminacije iz organizma taj kompleks ima velik potencijal u radi- odijagnostičkim tehnikama, poput primjerice pozitronske emisijske tomografije (krat. PET, engl. positron emission tomography).

\section{Antineurodegenerativni učinak 3,4-HP derivata}

Neurodegenerativne bolesti, poput Alzheimerove i Parkinsonove bolesti, okarakterizirane su stvaranjem proteinskih agregata u mozgu, što postupno vodi ka gubitku funkcije sinapsi i živčanih stanica (neurona) u moždanoj ovojnici. Kod Alzheimerove bolesti dolazi do izvanstanične akumulacije $\beta$-amiloidnih peptida (peptidi $\mathrm{A} \beta_{40}$ i $\mathrm{A} \beta_{42}$ ) u amiloidne ploče, a, kod Parkinsonove, proteina $\alpha$-sinukleina. Detalji mehanizama akumulacije tih proteina još uvijek se

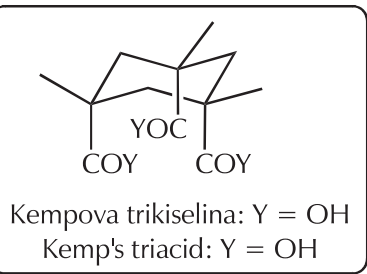

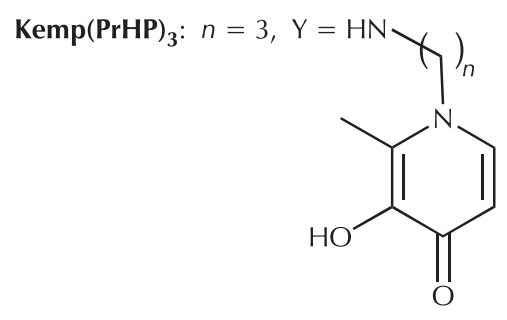

$\mathrm{pFe}=28, \log P=-1,04$
$\operatorname{Kemp}(\mathrm{BuHP})_{3}: n=4, \mathrm{Y}=\mathrm{HN} \longrightarrow$<smiles>C=NCCn1ccc(=O)c(O)c1C</smiles>

$\mathrm{pFe}=26,8, \log P=-0,62$
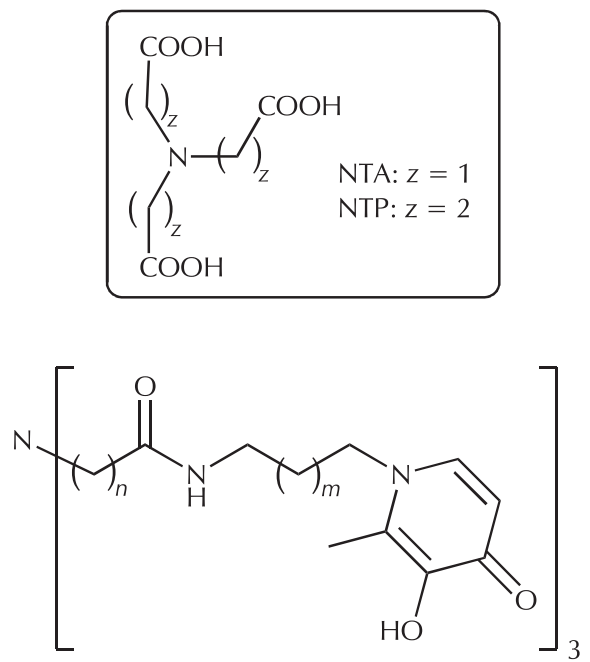

$$
\begin{aligned}
& \text { NTP(PrHP })_{3}: n=2, m=1 \quad \text { pFe }=29,4, \log P=-1,24 \\
& \text { NTA(BuHP) })_{3}: n=1, m=2 \quad \text { pFe }=27,9, \log P=-1,40
\end{aligned}
$$

Slika 2 - Strukturne formule te vrijednosti pFe i $\log P$ heksadentatnih tris(3,4-HP) kelatora trovalentnih iona metala ${ }^{18,19}$

Fig. 2 - Structural formulas, pFe and $\log P$ values for hexadentate tris(3,4-HP) M(III) chelators ${ }^{18,19}$ 


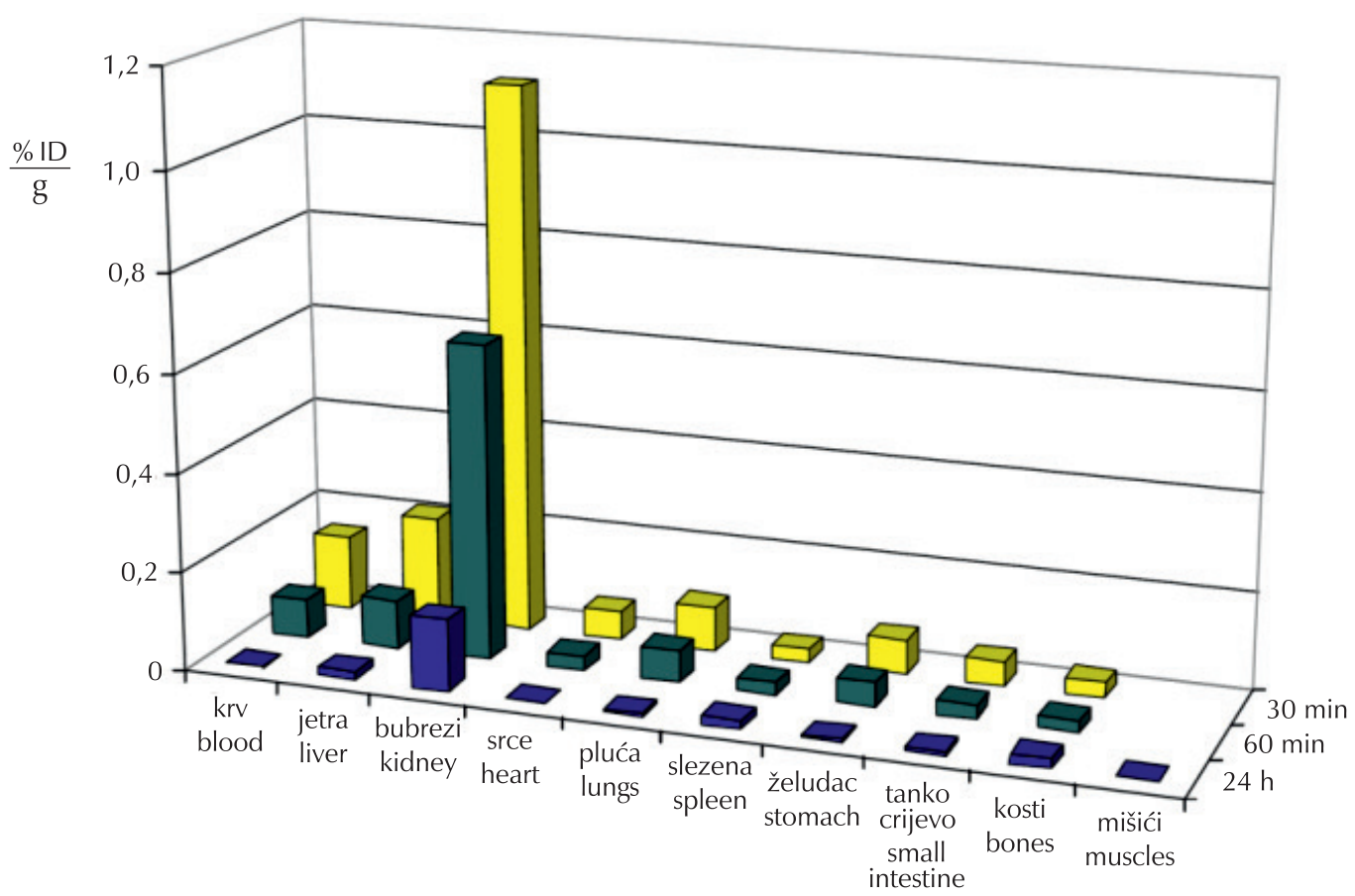

Slika 3 - Biodistribucijski profil u štakoru za kompleks ${ }^{67} \mathrm{Ga}-\mathrm{NTP}(\operatorname{PrHP})_{3}$. Mjerenja su provedena 0,5, 1 i $24 \mathrm{~h}$ nakon intravenoznog injektiranja i iskazana kao ovisnost postotka injektirane doze po gramu organa (\% ID / g). ${ }^{20}$

Fig. 3 - Biodistribution study for ${ }^{67} \mathrm{Ga}-\mathrm{NTP}(\mathrm{PrHP})_{3}$ complex in rat model. Measurements were conducted at $0.5,1$, and $24 \mathrm{~h}$ after intravenous injection and results presented as percentage of injected dose per gram of organ (\% ID / g) ${ }^{20}$

istražuju, kao i faktori koji ih iniciraju. ${ }^{21}$ Pretpostavlja se da u inicijaciji tih neuropatoloških procesa važnu ulogu imaju mutacije gena koji kodiraju navedene proteine. ${ }^{21}$

$\mathrm{A} \beta_{42}$ peptid stvara proteinske agregate znatno brže od $\mathrm{A} \beta_{40}$ peptida. Sastoji se od 42 aminokiselinska ostatka i nastaje, kao i $\mathrm{A} \beta_{40}$, proteolitičkim cijepanjem velikog transmembranskog glikoproteina pod nazivom prekursor amiloidnog proteina (krat. APP, engl. amyloid precursor protein) koje kataliziraju sekretaze. Agregacijom nastalih monomera nastaju dimeri, trimeri te u konačnici oligomerne vrste. Čak i male doze monomernih ili dimernih $\mathrm{A} \beta_{42}$ uzrokuju poremećaje u funkciji i održivosti živčanih stanica.

Smatra se da poremećaji u homeostazi nekih prijelaznih metala, poput željeza, bakra i cinka, igraju važnu ulogu $\mathrm{u}$ procesu akumulacije tih proteina. Primjerice, $\mathrm{A} \beta_{42}$ je metaloprotein s veznim mjestima za Fe(II) i Fe(III) u svojim N-terminalnim regijama te može doprinijeti oksidoreduktivnom ciklusu između ta dva kationa te nastanku ROS-vrsta. ${ }^{21,22}$ Postoje brojne studije koje povezuju stanični oksidativni stres, koji se javlja zbog povišenih koncentracija ovih iona, s neurodegenerativnim oboljenjima, ne samo u Parkinsonovoj i Alzheimerovoj bolesti već i u oboljenjima kao što su primjerice Friedreichova ataksija ili Huntingtonova bolest. ${ }^{11,22,23}$ ROS-vrste, kao što je već napomenuto, uzrokuju oštećenja mnogih važnih biomolekula. $U$ zdravom i mladom organizmu te se vrste brzo eliminiraju staničnim obrambenim mehanizmima, no, ako je njihova razina iznad dopuštene, dolazi do oksidativnog stresa. Poznato je da se oksidativni stres u mozgu povisuje s godinama starosti. No još nije razjašnjeno je li povezan s primarnim uzrocima spomenutih bolesti ili je posljedica njihove progresije. U slučaju Alzheimerove bolesti postoje literaturni dokazi koji povezuju oksidativne procese s nastalim proteinskim amiloidnim lezijama. Tako je, na primjer, inkubacijom Fe(II) te $\beta$-amiloidnih peptida ili $\alpha$-sinukleina vrlo brzo primijećeno nastajanje ROS-radikala koji su detektirani s pomoću elektronske paramagnetske rezonancije (krat. EPR, engl. electron paramagnetic resonance). ${ }^{24,25}$ Metodama in vitro uz detekciju spektroskopskim i mikroskopskim tehnikama dokazano je da inkubacijom imobiliziranih $\beta$-amiloidnih peptida s metalima poput $\mathrm{Fe}(\mathrm{III}), \mathrm{Cu}(\mathrm{II})$ ili $\mathrm{Zn}(\mathrm{II})$ isti kataliziraju stvaranje neželjenih $\mathrm{A} \beta_{42}$ agregata te ujedno mijenjaju i njihovu morfologiju. ${ }^{26}$

Idealan kelatoterapeutik, koji bi služio za uklanjanje željeza iz moždanog tkiva, trebao bi moći vezati željezo selektivno u tom organu, ali ne i u ostalim organima. Nastale kompleksne vrste bi se onda eliminirale iz organizma te bi se dodatno njihovim nastajanjem mogli spriječiti toksični procesi poput Fentonove reakcije jer bi željezo izgubilo svoj oksidoreduktivni karakter. To ujedno znači da bi kelator trebao ostvariti i odgovarajuće interakcije s amiloidnim proteinima. Najvažnije od svega, kelator treba uspješno proći krvno-moždanu barijeru (krat. BBB, engl. blood brain barrier), što znači da njegova molekulska masa mora biti manja od 300 Da. Molekulska masa kompleksa trebala bi 
zadovoljavati iste uvjete za uspješnu eliminaciju. DFO je bio prvi kelator koji je upotrebljen u tu svrhu, međutim, očekivano, njegov ipak previsoki hidrofilni karakter kao i molekulska masa otežavali su mu prolaz kroz BBB. Poželjno bi bilo da pripravljeni spoj ima i antioksidativna svojstva, odnosno da posjeduje takve strukturne motive koji bi omogućili spoju da djeluje kao "hvatač" ROS-radikalskih vrsta, čime bi mogao imati i dodatni neuroprotektivni učinak. Jedan od takvih motiva je primjerice fenolna skupina. Danas postoji niz jeftinih, dostupnih, brzih i učinkovitih metoda s pomoću kojih je moguće preliminarno in vitro ispitati antioksidativnu aktivnost nekog spoja. ${ }^{27}$

3,4-HP idealni su kandidati za keliranje željeza iz moždanog tkiva jer, osim što se radi o spojevima male molekulske mase, imaju visoku selektivnost za trovalentne katione metala u odnosu na dvovalentne. Mogu se lako sintetski modificirati, čime bi se mogao osigurati uspješan prolaz kroz BBB. Jedan od sintetskih postupaka koji se primjenjuju za bolju permeabilnost kroz BBB je glukozilacija što podrazumijeva uvođenje glukozne podjedinice u osnovnu 3,4-HP strukturu. S obzirom na to da je BBB, za razliku od ostalih membrana u organizmu, obogaćena membranskim proteinima koji služe transportu glukoze (krat. GLUT-1, engl. glucose transporter 1) kao i njezinih važnih bioderivata, pretpostavlja se da će oni moći poslužiti u prijenosu glikoziliranog spoja u moždano tkivo. Takav način prijenosa terapeutika već se uvelike primjenjuje, primjerice za transport analgetika, antitumorskih lijekova, lijekova za HIV (engl. human immunodeficiency virus) i sl. Glukozna se podjedinica može uvesti na različite položaje derivata 3,4-HP: a) na neku od funkcijskih skupina alkilne poveznice uvedene na položaj 1 piridinonskog dušikovog atoma, pri čemu nije nužno njezino cijepanje pomoću enzima nakon prolaska kroz BBB, ili b) na hidroksilnu skupinu na položaju 3 piridinonskog prstena čime se privremeno blokira kelirajuće vezno mjesto za željezo i zapravo pripravlja prolijek. U tom slučaju, nastala glikozidna veza se nakon prolaska kroz BBB mora pocijepati enzimskim putem s pomoću $\beta$-glukozidaza koje su, osim ostalog, prisutne i u mozgu. To drugim riječima znači da je potrebno sintetizirati 3,4-HP derivate s $\beta$-glukozidnim strukturnim motivom.

Prvim načinom pripravljen je feraleks-G (shema 2), koji se danas nalazi u predkliničkim ispitivanjima. Spoj uspješno prolazi BBB, kelira ne samo Fe(III) već i $\mathrm{Al}(\mathrm{III})$, te se ispituje i kao potencijalni kelatoterapeutik za liječenje toksičnog utjecaja aluminija na moždano tkivo, metala također usko povezanog s neurodegenerativnim oboljenjima. ${ }^{8,28}$ Izravnom metodom priprave, polazeći od maltola i glicina (Gly) pri $\mathrm{pH}=10,2$, najprije je pripravljen njegov 3,4-HP-prekursor TPAK-G. Amidna veza između karboksilne skupine glicina i D-glukozamina ostvarena je uporabom $N$-hidroksisukcinimida kao aktivatora karboksilne skupine i N,N'-dicikloheksilkarbodiimida (DCC) kao kondenzirajućeg reagensa.<smiles>Cc1occc(=O)c1O</smiles>

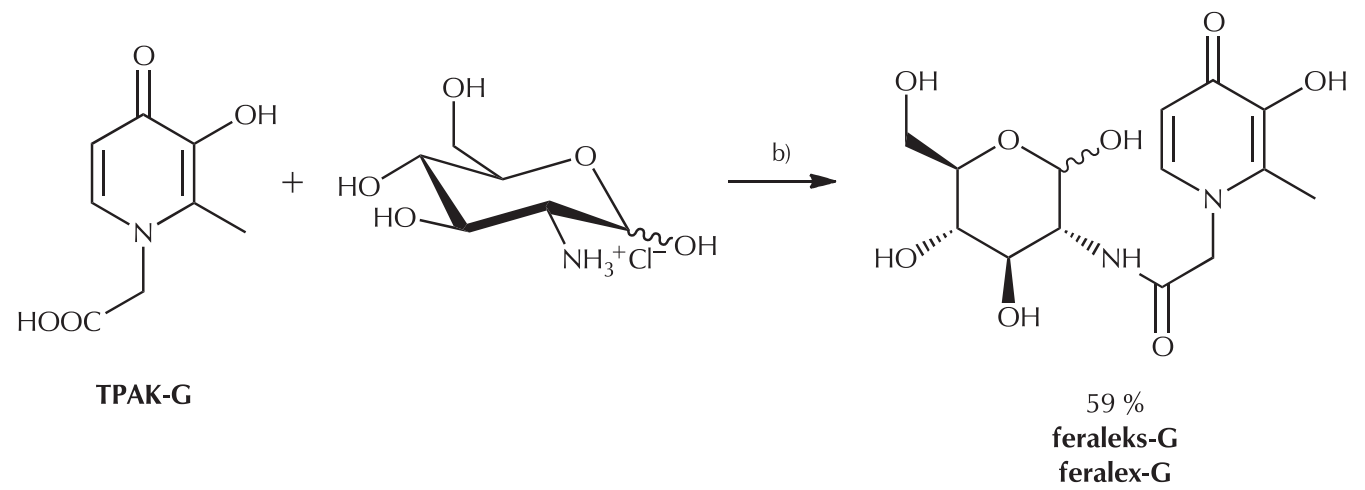

Shema 2 - Sinteza feraleksa-G: a) $\mathrm{H}_{2} \mathrm{O}, \mathrm{NaOH}, \mathrm{pH}=10,2,35^{\circ} \mathrm{C}, 5$ dana; b) N-hidroksisukcinimid, DCC, $\mathrm{Et}_{3} \mathrm{~N}, \mathrm{DMF}, 8 \mathrm{~h}^{28}$

Scheme 2 - Synthesis of feralex-G: a) $\mathrm{H}_{2} \mathrm{O}, \mathrm{NaOH}, \mathrm{pH}=10,2,35{ }^{\circ} \mathrm{C}, 5$ days; b) N-hydroxysuccinimide, DCC, $\mathrm{Et}_{3} \mathrm{~N}, \mathrm{DMF}, 8 \mathrm{~h}^{28}$ 
Primjenjujući drugu metodu O-glukozilacije položaja 3 Scott $i$ sur. pripravili su seriju $\beta$-O-glukozida $N$-alkilnih i $\mathrm{N}$-arilnih derivata $3,4-\mathrm{HP}$ (slika 4). ${ }^{29-31}$ Prije vezanja glukozne jedinice svim je sintetiziranim derivatima 3,4-HP najprije ispitana antioksidativna aktivnost s pomoću metode antioksidativnog učinka prema Troloxu (krat. TEAC, engl. Trolox equivalent antioxidant capacity). ${ }^{27} \mathrm{U}$ toj se metodi 2,2'-azinobis-(3-etilbenzotiazolin)-6-sulfonska kiselina (krat. ABTS, engl. 2,2'-azinobis(3-ethylbenzothiazoline)-6-sulfonic acid) najprije prevodi u radikal-kation $\left(\right.$ ABTS $^{\cdot+}$ ) koji absorbira na $745 \mathrm{~nm}$. Dodatkom spoja koji ima antioksidativnu aktivnost nastali $\mathrm{ABTS}^{*+}$ se neutralizi$\mathrm{ra}$, te se maksimum na toj valnoj duljini gubi. Mjerenjem apsorbancije i usporedbom s nekim standardom, primjerice vitaminom E, koji je poznati antioksidans, određuje se antioksidativni učinak spoja. Antioksidativni utjecaj svih ispitanih spojeva bio je jednak ili viši od vitamina E, čime se pokazalo da imaju potencijalni neuroprotektivni učinak. Općenito su se najboljima pokazali $\mathrm{N}$-arilni derivati za razliku od $N$-alkilnih, što se objašnjava mogućnošću dodatne delokalizacije elektrona kod nastalih radikalskih vrsta. Spojevi L3-L5, L9 i L10 izabrani su za ispitivanje citotoksičnosti uz cisplatin kao standard, poznati kemoterapeutik s izraženim citotoksičnim djelovanjem. Pokusi in vitro provedeni su na tumorskim staničnim linijama jetre (HepG2) ili dojke (MDA-MB-435S) te su svi ispitani spojevi okarakterizirani kao netoksični. Primjerice, vrijednost $\mathrm{IC}_{50}$ za cisplatin je $35 \pm 5 \mu \mathrm{M}$ dok je za $\mathbf{L} \mathbf{5}$ derivat ona bila puno viša i iznosila $570 \pm 90 \mu \mathrm{M}$.

Istim spojevima je, uz deferipron (L1), ispitana njihova mogućnost resolubilizacije (deagregacije proteina) pomoću sintetskog liofiliziranog ljudskog amiloidnog peptida $A \beta_{1-40}$ koji može agregirati in vitro $\mathrm{i}$ in vivo u prisutnosti $\mathrm{Zn}(\mathrm{II}) \mathrm{i}$ $\mathrm{Cu}(\mathrm{II})$. Svi spojevi umanjuju postotak agregacije u odnosu na dietilentriaminpentaoctenu kiselinu (DPTA) koja je upotrijebljena kao standard. Nakon uvođenja glukozne jedinice odabrani dobiveni glikozidi G1-G6 podvrgnuti su djelovanju enzima $\beta$-glukozidaze iz Agrobacterium sp. Reakcije su praćene preliminarno tankoslojnom kromatografijom, a potom i spektrofotometrijski. Kod svih je glikozida primijećeno cijepanje glikozidne veze. Jednom je predstavniku (G12) tih derivata ispitana mogućnost prolaska kroz BBB na modelu štakora uz tri referentna spoja. Kafein i nikotin

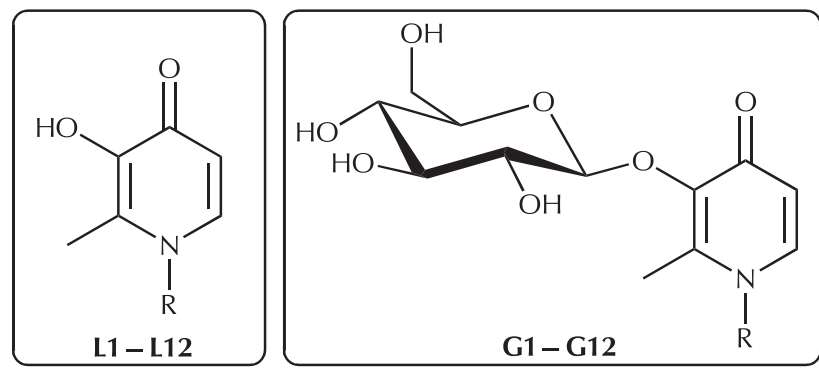

$\mathrm{R}=\mathrm{CH}_{3} \mathbf{1}, \quad \mathrm{C}_{6} \mathrm{H}_{13} 2$<smiles>[Z6]Cc1ccccc1</smiles>

3<smiles>Cc1ccc(N)cc1</smiles>

9<smiles>Cc1ccc(C(C)C)cc1</smiles>

5<smiles>O=[N+]([O-])c1ccc(O)cc1</smiles>

6<smiles>CN(C)c1ccc(C(C)(C)C)cc1</smiles>

7<smiles>CNc1ccc([N+](=O)[O-])cc1</smiles>

8<smiles>Cc1ccc2ncsc2c1</smiles>

10<smiles>Cc1nc2ccccc2s1</smiles>

11<smiles>Cc1nc(-c2ccc(Br)cc2)cs1</smiles>

Slika 4 - $\beta$-O-glukozidni $N$-alkilni i $N$-arilni derivati 3,4-HP - potencijalni prolijekovi u liječenju Alzheimerove bolesti ${ }^{29-31}$

Fig. 4 - $\beta$-O-glucosydic $N$-alkyl and N-aryl 3,4-HP derivatives - potential prodrugs for Alzheimer's disease ${ }^{29-31}$ 

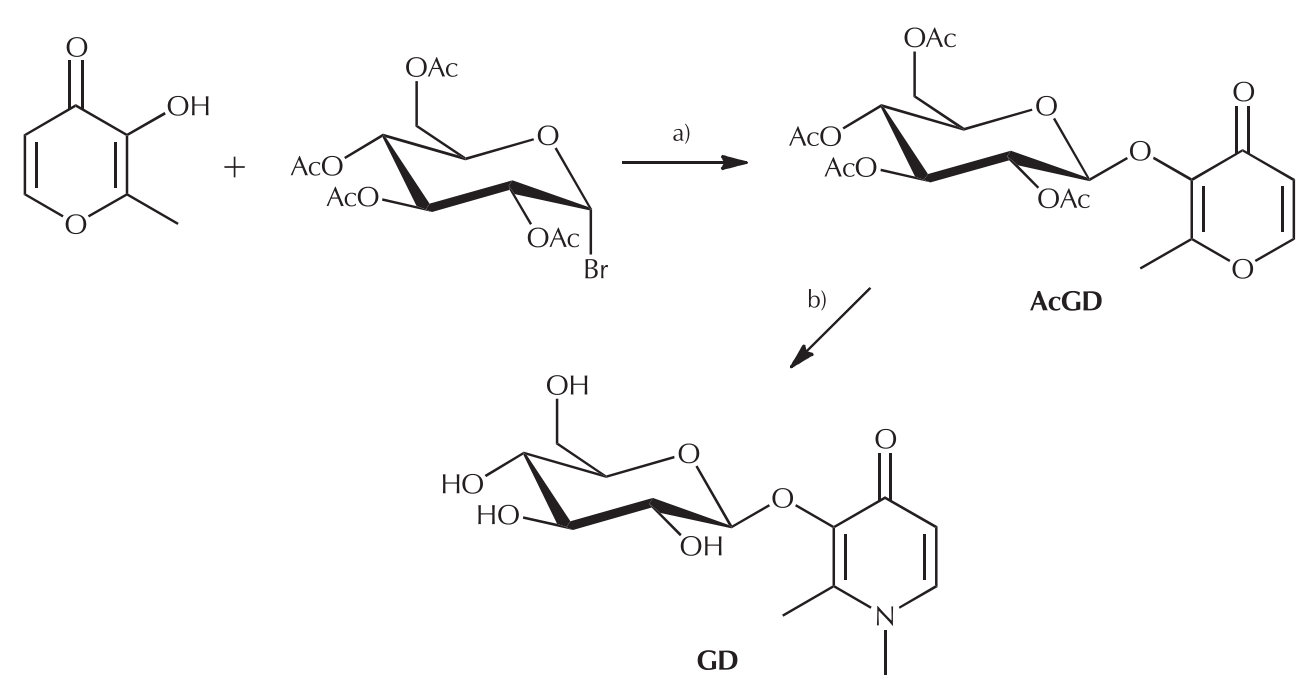

Shema 3 - Priprava $\beta$-O-glukozida deferiprona: a) TBAB, $1 \mathrm{M} \mathrm{NaOH}, \mathrm{DCM}, 35{ }^{\circ} \mathrm{C}, 3 \mathrm{~h}, 43 \%$; b)
obujamski omjer EtOH/ $\mathrm{H}_{2} \mathrm{O} 1: 1,40 \% \mathrm{CH}_{3} \mathrm{NH}_{2}, 70{ }^{\circ} \mathrm{C}, 24 \mathrm{~h}, 82 \%{ }^{32}$
Scheme 3 - Preparation of $\beta$-O-glucoside of deferiprone: a) TBAB, $1 \mathrm{M} \mathrm{NaOH}, \mathrm{DCM}, 35{ }^{\circ} \mathrm{C}, 3 \mathrm{~h}, 43$
\%; b) volume ratio EtOH/ $\mathrm{H}_{2} \mathrm{O} 1: 1,40 \% \mathrm{CH}_{3} \mathrm{NH}_{2}, 70{ }^{\circ} \mathrm{C}, 24 \mathrm{~h}, 82 \%{ }^{32}$

su upotrijebljeni kao pozitivni kontrolni standardi s obzirom na to da brzo i lako prolaze krvno-moždanu barijeru, dok je saharoza poslužila kao negativni kontrolni referentni spoj. G12 je radioaktivno obilježen uvođenjem ${ }^{125}$ I umjesto broma u para-položaj fenilnog prstena. Iznos permeabilnosti radioaktivno obilježenog G12 bila je između iznosa pozitivnih i negativnih referentnih spojeva. S obzirom na to da je za referentne spojeve poznato da prolaze BBB pasivnim načinom membranskog prijenosa, konkretno difuzijom, zaključeno je da su za prijenos ispitivanog spoja vjerojatno odgovorni drugačiji transportni mehanizmi poput već spomenutog GLUT-1.

Metoda uvođenja glukozne jedinice na 3,4-HP strukturu radi olakšanog prolaska kroz BBB još je uvijek predmet rasprave. Naime, Roy i sur. ${ }^{32}$, među kojima je i Hider, proveli su istraživanje na deferipronu te se pokazalo da deferipron bez glukozne jedinice prolazi BBB, dok njegov glukozilirani analog to ne može. Spojevi su sintetizirani polazeći od maltola i 2,3,4,6-tetra-O-acetil-1-brom- $\alpha$-D-glukopiranoze, pri čemu je najprije pripravljen zaštićeni derivat AcGD (shema 3). Željeni spoj GD sintetiziran je izravnom metodom te je u istome koraku uklonjena i acetilna zaštitna skupina. Izravna metoda je u tom radu prvi put primijenjena na glikozidni 3,4-HP derivat. Eksperimenti su provedeni in vivo na modelu zamorčića metodom moždane in situ perfuzije. Tom se tehnikom željena tvar u moždano tkivo životinjskog modela uvodi infuzijom kroz krvotok tako da se određena koncentracija ispitivanog spoja pomiješa s nekim medijem, obično umjetnom krvi, plazmom ili elektrolitnom otopinom. Nakon nekog vremena perfuzija se zaustavlja i određuje se količina tvari kao i njezina distribucija u mozgu. Iz tih se mjerenja može odrediti kinetika unosa te izračunati odgovarajuće konstante permeabilnosti odnosno transporta. Rezultati dobiveni tom metodom pokazali su da, za razliku od deferiprona, njegov glukozilirani derivat GD uopće ne prolazi kroz BBB.

\section{Ostali važni biološki učinci 3,4-HP}

Jedan od načina potencijalnog antitumorskog djelovanja kelatora zasniva se na vezanju željeza, pri čemu se tumorskoj stanici oduzima moć proliferacije. Naime, poznato je da tumorske stanice imaju veću potrebu za željezom od zdravih stanica s obzirom na činjenicu da brzo proliferiraju. Stoga je u njima metabolizam željeza izmijenjen. ${ }^{11,33,34}$ Primjerice, za razliku od zdravih stanica, tumorske stanice imaju veći broj transferinskih receptora na površini što dopušta veći unos željeza. Već spomenuti RR, kojemu je za aktivnost potrebno željezo, katalizira redukciju ribonukleotida u njihove odgovarajuće deoksiribonukleotidne analoge važne za sintezu DNA. Inaktivacija ovoga enzima uzrokuje prestanak sinteze DNA odnosno terminaciju proliferacije. Dakle, keliranjem željeza iz skladišnih odjeljaka u tumorskim stanicama moglo bi se utjecati na njihovu proliferaciju uskraćivanjem DNA nukleotidnih prekursora.

In vitro i klinička istraživanja ${ }^{34,35}$ pokazala su da su agresivni tumori poput leukemije vrlo osjetljivi na terapiju keliranja željeza s pomoću DFO-a. Dokazano je da se njegovo antiproliferativno djelovanje ispoljava osiromašivanjem stanice željezom i na taj način inhibira enzim RR. Međutim, iako je pokazao antitumorski učinak, njegova mu hidrofilnost donekle snizuje učinkovitost zbog već spomenute slabe membranske permeabilnosti. Za deferipron se pokazalo da keliranjem željeza uzrokuje prekid sinteze DNA te apoptozu tumorske stanice in vitro. No, u ispitivanjima in vivo na mišjem modelu rezultati su bili oprečni jer nije pokazao značajniju antitumorsku aktivnost. ${ }^{34}$

Od ostalih vrsta bioloških aktivnosti koju pokazuju derivati 3,4-HP treba još spomenuti antimalarijsku, ${ }^{36}$ antibakterijsku $^{37}$ te antiadhezijsku ${ }^{4}$ aktivnost. Pokazalo se da ti spojevi mogu inhibirati rast mnogih bakterija te da je, osim sposobnosti keliranja željeza, nekoliko dodatnih strukturnih faktora važno u pokazivanju navedenog učinka. Neki od njih 
su uvođenje alkilaminskih ili alkilamidnih supstituenata na dušikov atom piridinonskog skeleta ili supstitucija položaja 2 i $6 .^{1,37}$ Antiadhezijska aktivnost tih derivata, prvi je put ispitana na $\alpha$-manozidnim derivatima $N$-aril supstituiranih 3,4-HP in vitro uporabom testa inhibicije hemaglutinacije (test inhibicije aglutinacije uropatogene bakterije E. coli na eritrocite iz krvi zamorčića). Pokazalo se da svi spojevi umjereno inhibiraju hemaglutinaciju. Provedena je i studija molekulskog modeliranja kojom su istaknute specifične interakcije odgovorne za uočenu aktivnost prema bakterijskom FimH lektinu, čime je otvoren put dizajnu novih potencijalnih inhibitora. Otkad je ispitan učinak DFO u liječenju malarije, za liječenje te bolesti počelo je ispitivanje i mnogih drugih kelatora pa tako i 3,4-HP derivata. Neki od njih pokazali su se uspješnima in vitro i in vivo s vrijednostima infektivnih doza $\mathrm{ID}_{50} 15-45 \mu \mathrm{M}$, ovisno o derivatu. ${ }^{36}$

\section{Zaključak}

Heterociklički 3,4-HP derivati su svestrani biološki agensi ponajprije zahvaljujući svojoj sposobnosti keliranja trovalentnih metalnih kationa. U fiziološkim uvjetima imaju izrazito visok afinitet za Fe(III), usporediv čak s transferinom, te se stoga najviše ispituju za liječenje bolesti koje rezultiraju prekomjerenim nakupljanjem tog metala u organizmu. Deferipron je, za sada, jedini klinički odobren 3,4-HP derivat koji se upotrebljava za tu vrstu oboljenja. U novije vrijeme polidentatni 3,4-HP analozi postali su iznimno popularni i tek se trebaju ispitati metodama in vivo. 3,4-HP pokazuju i antineurodegenerativni učinak, prije svega kao potencijalni antioksidansi jer keliranjem željeza i/ili reakcijom s radikalskim vrstama prisutnim u moždanom tkivu umanjuju oksidativni stres.

\section{ZAHVALA}

Autorice se posebno zahvaljuju Hrvatskoj zakladi za znanost za potporu ovoga rada u sklopu projekta IP-2014-097899 Sinteza, strukturna analiza i biološka evaluacija peptidomimetika i glikokonjugata.

\section{Popis kratica i simbola List of abbreviations and symbols}

\begin{tabular}{|c|c|}
\hline ABTS & $\begin{array}{l}\text { - 2,2'-azinobis(3-etilbenzotiazolin)-6-sulfonska kiselina } \\
\text { - 2,2'-azinobis(3-ethylbenzothiazoline)-6-sulfonic acid }\end{array}$ \\
\hline APP & $\begin{array}{l}\text { - prekursor amiloidnog proteina } \\
\text { - amyloid precursor protein }\end{array}$ \\
\hline ATP & $\begin{array}{l}\text { - adenozin-trifosfat } \\
\text { - adenosine triphosphate }\end{array}$ \\
\hline BBB & $\begin{array}{l}\text { - krvno-moždana barijera } \\
\text { - blood-brain barrier }\end{array}$ \\
\hline DCC & $\begin{array}{l}\text { - N,N'-dicikloheksilkarbodiimid } \\
-N, N^{\prime} \text {-dicyclohexylcarbodiimide }\end{array}$ \\
\hline DCM & $\begin{array}{l}\text { - diklormetan } \\
\text { - dichloromethane }\end{array}$ \\
\hline DFO & $\begin{array}{l}\text { - desferioksamin B } \\
\text { - desferrioxamine B }\end{array}$ \\
\hline
\end{tabular}

DMF $\quad-N, N$-dimetilformamid

- N,N-dimethylformamide

DMT1 - transportni protein 1 za dvovalentne katione metala

- divalent metal transporter 1

DPTA - dietilentriaminpentaoctena kiselina

- diethylenetriaminepentaacetic acid

EPR - elektronska paramagnetska rezonancija

- electron paramagnetic resonance

Et3N - trietilamin

- triethylamine

GLUT-1 - transportni protein 1 za prijenos glukoze

- glucose transporter 1

HP - hidroksipiridinoni

- hydroxypyridinones

LIP - nestabilni odjeljak za željezo

- labile iron pool

NTA - nitrilotrioctena kiselina

- nitrilotriacetic acid

NTP - nitrilotripropanska kiselina

- nitrilotripropionic acid

PET - pozitronska emisijska tomografija

- positron emission tomography

ROS - reaktivne kisikove vrste

- reactive oxygen species

RR - ribonukleotid-reduktaza

- ribonucleotide reductase

SAR - odnos strukture i aktivnosti

- structure-activity relationship

TBAB - tetra- $n$-butilamonijev bromid

- tetra- $n$-butylammonium bromide

TEAC - metoda antioksidativnog učinka prema Troloxu

- Trolox equivalent antioxidant capacity

Tf $\quad-$ transferin

- transferrin

TfR1 - transferinski receptor 1

- transferrin receptor 1

$P \quad-$ koeficijent particije (razdiobe)

- partition coefficient

\section{Literatura}

\section{References}

1. M. A. Santos, S. Chaves, 3-Hydroxypyridinone derivatives as metal sequestering agents for therapeutic use, Future Med. Chem. 7 (2015) 383-410, doi: https://doi.org/10.4155/ fmc.14.162.

2. W. Kandioller, A. Kurzwernhart, M. Hanif, S. M. Meier, H. Henke, B. K. Keppler, C. G. Hartinger, Pyrone derivatives and metals: From natural products to metal-based drugs, J. Organomet. Chem. 696 (2011) 999-1010, doi: https://doi. org/10.1016/j.jorganchem.2010.11.010.

3. M. A. Santos, S. M. Marques, S. Chaves, Hydroxypyridinones as "privileged" chelating structures for the design of medicinal drugs, Coord. Chem. Rev. 256 (2012) 240-259, doi: https://doi.org/10.1016/j.ccr.2011.08.008.

4. Ž. Car, T. Hrenar, V. Petrović Peroković, R. Ribić, M. Seničar, S. Tomić, Mannosylated N-aryl substituted 3-hydroxypyridine-4-ones: Synthesis, hemagglutination inhibitory properties and molecular modeling, Chem. Biol. Drug Des. 84 (2014) 393-401, doi: https://doi.org/10.1111/cbdd.12329. 
5. V. Petrović Peroković, A. Gojmerac Ivšić, Ž. Car, S. Tomić, Synthesis of 3-hydroxy-1-(p-methoxyphenyl)-2-methylpyridine-4-one and spectrophotometric extraction studies on its complexation of vanadium(V), Croat. Chem. Acta 87 (2014) 103-109, doi: https://doi.org/10.5562/cca2366.

6. V. Petrović Peroković, B. Prugovečki, Ž. Car, Synthesis, crystal and molecular structure of novel adamantyl derivatives of $\mathrm{N}$-aryl substituted 3-hydroxy-2-methylpyridine-4-ones, Croat. Chem. Acta 86 (2013) 317-323, doi: https://doi. org/10.5562/cca2339.

7. A. Gojmerac Ivšić, V. Tomišić, Ž. Car, B. Prugovečki, S. Tomić, Synthesis and characterization of a new 4-pyridone derivative and its complexation of iron(III), J. Mol. Str. 990 (2011) 237243, doi: https://doi.org/10.1016/j.molstruc.2011.01.051.

8. M. A. Santos, Recent developments on 3-hydroxy-4-pyridinones with respect to their clinical applications, Mono and combined ligand approaches, Coord. Chem. Rev. 252 (2008) 1213-1224, doi: https://doi.org/10.1016/j.ccr.2008.01.033.

9. J. Shao, B. Zhou, B. Chu, Y. Yen, Ribonucleotide Reductase Inhibitors and Future Drug Design, Curr. Cancer Drug Tar. 6 (2006) 409-431, doi: https://doi.org/10.2174/1568009067 77723949.

10. R. W. Evans, X. Kong, R. C. Hider, Iron mobilization from transferrin by therapeutic iron chelating agents, Biochim. Biophys. Acta - Gen. Subj. 1820 (2012) 282-290, doi: https:// doi.org/10.1016/j.bbagen.2011.11.007.

11. D. S. Kalinowski, D. R. Richardson, The Evolution of Iron Chelators for the Treatment of Iron Overload Disease and Cancer, Pharmacol. Rev. 57 (2005) 547-583, doi: https:// doi.org/10.1124/pr.57.4.2.

12. L. Saghaie, R. C. Hider, Synthesis and physico-chemical properties of a series of bidentate 3-hydroxypyridin-4-ones iron chelating agents, Res. Pharm. Sci. 3 (2008) 21-30.

13. L. Saghaie, M. Mirmohammad Sadeghi, A. Nikazma, Synthesis, analysis and determination of partition coefficients of $\mathrm{N}$-arylhydroxypyridinone derivatives as iron chelators, Res. Pharm. Sci. 1 (2006) 40-48.

14. M. A. Santos, M. Gil, S. Marques, L. Gano, G. Cantinho, S. Chaves, N-Carboxyalkyl derivatives of 3-hydroxy-4-pyridinones: Synthesis, complexation with Fe(III), $\mathrm{Al}(\mathrm{III})$ and $\mathrm{Ga}(\mathrm{III})$ and in vivo evaluation, J. Inorg. Biochem. 92 (2002) 43-54, doi: https://doi.org/10.1016/S0162-0134(02)00483-X

15. D. E. Green, C. L. Ferreira, R. V. Stick, B. O. Patrick, M. J. Adam, C. Orvig, Carbohydrate-bearing 3-hydroxy-4-pyridinonato complexes of gallium(III) and indium(III), Bioconjugate Chem. 16 (2005) 1597-1609, doi: https://doi. org/10.1021/bc0501808

16. Z. Zhang, T. L. Thomas Hui, C. Orvig, One-pot synthesis of $\mathrm{N}$-substituted-3-hydroxy-4-pyridinone chelate complexes of aluminum, gallium, and indium, Can. J. Chem. 67 (1989) 1708-1710, doi: https://doi.org/10.1139/v89-263.

17. D. S. Kemp, K. S. Petrakis, Synthesis and conformational analysis of cis, cis-1,3,5-trimethylcyclohexane-1,3,5-tricarboxylic acid, J. Org. Chem. 46 (1981) 5140-5143, doi: https:// doi.org/10.1021/jo00338a014.

18. R. Grazina, L. Gano, J. Šebestík, M. A. Santos, New tripodal hydroxypyridinone based chelating agents for Fe(III), Al(III) and Ga(III): Synthesis, physico-chemical properties and bioevaluation, J. Inorg. Biochem. 103 (2009) 262-273, doi: https://doi.org/10.1016/j.jinorgbio.2008.10.014.

19. T. Zhou, R. C. Hider, X. Kong, Mode of iron(III) chelation by hexadentate hydroxypyridinones, Chem. Commun. 51 (2015) 5614-5617, doi: https://doi.org/10.1039/ c4cc10339d.

20. S. Chaves, A. C. Mendonça, S. M. Marques, M. I. Prata, A. C. Santos, A. F. Martins, C. F. G. C. Geraldes, M. A. Santos,
A gallium complex with a new tripodal tris-hydroxypyridinone for potential nuclear diagnostic imaging: solution and in vivo studies of ${ }^{67} \mathrm{Ga}$-labeled species, J. Inorg. Biochem. 105 (2011) 31-38, doi: https://doi.org/10.1016/j.jinorgbio.2010.09.012

21. R. C. Hider, Y. Ma, F. Molina-Holgado, A. Gaeta, S. Roy, Iron chelation as a potential therapy for neurodegenerative disease, Biochem. Soc. Trans. 36 (2008) 1304-1308, doi: https://doi.org/10.1042/BST0361304.

22. O. Myhre, H. Utkilen, N. Duale, G. Brunborg, T. Hofer, Metal Dyshomeostasis and Inflammation in Alzheimer's and Parkinson's diseases: Possible impact of environmental exposures, Oxidative Med. Cell. Longev. 2013 (2013) 1-19, doi: https://doi.org/10.1155/2013/726954.

23. L. E. Scott, C. Orvig, Medicinal inorganic chemistry approaches to passivation and removal of aberrant metal ions in disease, Chem. Rev. 109 (2009) 4885-4910, doi: https:// doi.org/10.1021/cr9000176.

24. D. G. Smith, R. Cappai, K. J. Barnham, The redox chemistry of the Alzheimer's disease amyloid $\beta$-peptide, Biochim. Biophys. Acta - Biomembr. 1768 (2007) 1976-1990, doi: https://doi.org/10.1016/j.bbamem.2007.02.002.

25. V. Dias, E. Junn, M. M. Mouradian, The role of oxidative stress in Parkinson's disease, J. Parkinsons Dis. 3 (2013) 461-491, doi: https://doi.org/10.3233/JPD-130230.

26. J. Ryu, K. Girigoswami, C. Ha, S. Hee Ku, C. Beum Park, Influence of multiple metal ions on $\beta$-amyloid aggregation and dissociation on a solid surface, Biochemistry 47 (2008) 5328-5335, doi: https://doi.org/10.1021/bi800012e.

27. Md. Nur Alam, N. J. Bristi, Md. Rafiquzzaman, Review on in vivo and in vitro methods evaluation of antioxidant activity, Saudi Pharm. J. 21 (2013) 143-152, doi: https://doi. org/10.1016/j.jsps.2012.05.002.

28. T. P. A. Krucka, T. E. Burrow, Synthesis of feralex a novel aluminum / iron chelating compound, J. Inorg. Biochem. 88 (2002) 19-24, doi: https://doi.org/10.1016/S01620134(01)00372-5.

29. L. E. Scott, M. Telpoukhovskaia, C. Rodríguez-Rodríguez, M. Merkel, M. L. Bowen, B. D. G. Page, D. E. Green, T. Storr, F. Thomas, D. D. Allen, P. R. Lockman, B. O. Patrick, M. J. Adam, C. Orvig, N-Aryl-substituted 3-( $\beta$-D-glucopyranosyloxy)-2-methyl-4(1H)-pyridinones as agents for Alzheimer's therapy, Chem. Sci. 2 (2011) 642-648, doi: https://doi. org/10.1039/COSC00544D.

30. L. E. Scott, B. D. G. Page, B. O. Patrick, C. Orvig, Altering pyridinone $N$-substituents to optimise activity as potential prodrugs for Alzheimer's disease, Dalton Trans. 38 (45) (2008) 6364-6367, doi: https://doi.org/10.1039/B815404J

31. D. E. Green, M. L. Bowen, L. E. Scott, T. Storr, M. Merkel, K. Böhmerle, K. H. Thompson, B. O. Patrick, H. J. Schugar, C. Orvig, In vitro studies of 3-hydroxy-4-pyridinones and their glycosylated derivatives as potential agents for Alzheimer's disease, Dalton Trans. 39 (2010) 1604-1615, doi: https:// doi.org/10.1039/B918439B.

32. S. Roy, J. E. Preston, R. C. Hider, Y. M. Ma, Glucosylated Deferiprone and its brain uptake: Implications for developing glucosylated hydroxypyridinone analogues intended to cross the blood-brain barrier, J. Med. Chem. 53 (2010) 5886-5889, doi: https://doi.org/10.1021/jm100380k.

33. Y. Yu, E. Gutierrez, Z. Kovačević, F. Saletta, P. Obeidy, Y. S. Rahmanto, D. R. Richardson, Iron chelators for the treatment of cancer, Curr. Med. Chem. 19 (2012) 2689-2702, doi: https://doi.org/10.2174/092986712800609706.

34. A. M. Merlot, D. S. Kalinowski, D. R. Richardson, Novel chelators for cancer treatment: Where are we now? Antiox. Redox Signal. 18 (2013) 973-1006, doi: https://doi. 
org/10.1089/ars.2012.4540.

35. Anthony Kicic, Anita C G Chua, Erica Baker, Desferrithiocin is a more potent antineoplastic agent than desferrioxamine, Br. J. Pharmacol. 135 (2002) 1393-1402, doi: https://doi. org/10.1038/sj.bjp.0704507.

36. L. S. Dehkordi, Z. D. Liu, R. C. Hider, Basic 3-hydroxypyridin-4-ones: Potential antimalarial agents, Eur. J. Med. Chem.
43 (2008) 1035-1047, doi: https://doi.org/10.1016/j.ejmech.2007.07.011.

37. A. Fassihi, D. Abedi, L. Saghaie, R. Sabet, H. Fazeli, G. Bostaki, O. Deilami, H. Sadinpour, Synthesis, antimicrobial evaluation and QSAR study of some 3-hydroxypyridine-4-one and 3-hydroxypyran-4-one derivatives, Eur. J. Med. Chem. 44 (2009) 2145-2157, doi: https://doi.org/10.1016/j.ejmech.2008.10.022.

\section{SUMMARY \\ 3-Hydroxypyridin-4-ones (Part II): Biological Application as Iron Chelating Agents \\ Željka Car, Vesna Petrović Peroković, and Srđanka Tomić Pisarović}

Selectivity towards trivalent metal cations, especially Fe(III), is the primary basis of a number of 3-hydroxypyridin-4-ones' biological activities. These compounds have high potential in the treatment of iron overload diseases, in various blood pathologies such as thalassemia and hemochromatosis, as well as in the treatment of neurodegenerative diseases, such as Alzheimer's disease. Beside deferiprone, the only 3-hydroxypyridin-4-one based iron(III) chelating agent which has been used clinically for more than 30 years, this review will also present other most significant and potentially biologically active chelators with 3-hydroxypyridin-4-one core.

\section{Keywords}

3-hydroxypyridin-4-ones, iron(III), chelation based therapeutics, deferiprone, thalassemia, Alzheimer's disease

Division of Organic Chemistry, Department of Chemistry, Faculty of Science, University of Zagreb,

Review Horvatovac 102A, HR-10 000 Zagreb, Croatia 